\title{
LYSIMELEIA (THUCYDIDES 7.53, THEOCRITUS 16.84): WHAT THUCYDIDES DOES NOT TELL US ABOUT THE SICILIAN EXPEDITION
}

\author{
RICHARD RAWLES \\ University of Edinburgh*
}

\begin{abstract}
In this paper, it is proposed that the lake Lysimeleia, mentioned by Thucydides in his account of the latter part of the Sicilian Expedition and by Theocritus in his encomium of Hieron II of Sicily, is likely to have been a sacred lake to the two goddesses Demeter and Kore. This suggestion is integrated into a way of reading the relevant passages in Thucydides and Theocritus, and its possible implications in the context of early discourses concerning the Athenian campaign at Syracuse are explored. In particular, this episode is read as one which can help us to consider the significance of Thucydides' tendency to downplay religious aspects of the events he describes and to speculate about what sorts of discourses about the Sicilian Expedition might have circulated among others, who would have been likely to consider such questions very differently.
\end{abstract}

Keywords: Thucydides, Theocritus, Syracuse, historiography, religion

\section{Thucydides 7.53}

At Thucydides 7.53, it is already becoming apparent that in the Sicilian Expedition the tide is turning against the Athenians. The Syracusans' tails are up and they have achieved a small victory by way of a sortie (7.51), prior to a naval victory in which Eurymedon has been killed and the Athenian ships driven to the shore (7.52).

However, at this point there is a slight change of fortunes:

When Gylippus saw the enemy ships being defeated and driven back to shore beyond their palisade and the confines of their base, he took part of his army along the spit $[\chi \eta \lambda \eta$ ' to intervene, with the intention of killing the sailors as they landed and making it easier for the Syracusans to tow away the ships from a shore now under friendly control. This part of the Athenian perimeter was guarded by the Etruscans. They could see a disorderly approach by Gylippus' troops and came out to confront them: they fell on the leading column, routed them, and drove the whole force into the marsh $[\lambda i \mu v \eta]$ called Lysimeleia. But afterwards the Syracusans and their allies brought up a larger force, and now the Athenians, in fear for their ships, came to support the Etruscans and joined battle with the enemy. They defeated and pursued the Syracusans, killing a few hoplites, and rescued most of their ships and brought them back to their base: but eighteen ships were captured by the Syracusans and their allies, and all the crews were executed. In an attempt to set fire to the remainder of the Athenian fleet the Syracusans filled an old merchant ship with brushwood and pine logs and, with the wind in the right direction, set light to it and let it drift towards the Athenians. Put in fear again for their ships the Athenians devised counter-measures to extinguish the flames and keep the fireship at a distance, and so averted the danger (7.53, tr. Hammond, Oxford World's Classics).

\footnotetext{
* richard.rawles@ed.ac.uk. This paper derives from encountering Lucia Prauscello's work on the cults of Hermione at the same time as I was working on Theocritus 16 for quite other purposes, and special thanks are due for her generosity with her forthcoming work and for discussion of the issues which I explore here. Thanks are also due to Simon Hornblower, who responded with generous encouragement to an early
}

suggestion of some of the ideas in this paper, and to Jason Crowley, Alan Griffiths, Elizabeth Irwin and Maria Pretzler for comment and advice, as well as to two anonymous readers and the editor of this journal. None of these should be assumed to agree with what follows, and responsibility for errors and folly remains my own. Translations, where not otherwise acknowledged, are my own. 
Next, both sides set up trophies for their victories (the Syracusans for their naval victory and the Athenians for the episode by the shore) (7.54) and the emphasis returns to despair for the Athenians (7.55) and the Syracusans' plan to turn besiegers into besieged by closing the mouth of the harbour (7.56). So the momentum towards disaster is not checked for long - but it is checked briefly. The rapid switches of fortune in this short passage are highlighted by the repeated emphasis on the notion of help or rescue (first Gylippus $\pi \alpha \rho \varepsilon \beta$ ó $\eta \theta \varepsilon$, then the Etruscans are

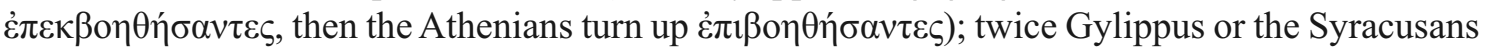
are $\beta$ ov $\lambda$ ó $\mu \varepsilon v o \varsigma$ ( $\beta$ ov $\lambda$ ó $\mu \varepsilon v o r)$, but twice their plans are thwarted. The feared, but averted, Athenian

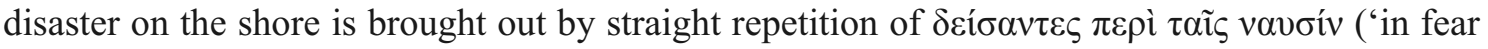
for their ships'). For some readers, given the narrowly averted danger of fire to the attackers' ships, an intertext will have been the battle by the ships in Iliad 15-16 (especially given the more overtly Iliadic qualities of the latter parts of the book); ${ }^{1}$ but this provokes reflection on differences at least as much as similarities. The attempted firing of the ships in the Iliad is a temporary success for the defenders in a story where we know that their city will ultimately be sacked; here the successful defence of the shore and the ships is a temporary respite for the attackers in an expedition which will fail. ${ }^{2}$

\section{Lysimeleia: its situation and name}

My particular concern is with a detail in this passage which may shed some light on Thucydides' treatment of this episode and of the Athenians' failure at Syracuse. Close to the Athenians' fortified camp beside the shore of the Great Harbour is a spit of land or breakwater $(\chi \eta \lambda \eta \dot{)}$ closely associated with a lake or marsh $(\lambda i \mu v \eta)$, along which Gylippus attacked for the purposes of (a) killing the Athenians as they disembarked from their ships and (b) making it easier for the Syracusans to drag off Athenian ships by bringing a part of the shore under the control of the defending forces.

Sense seems to demand that the spit of land divides the lake from the sea. Beyond this, the topography is hard to work out with precision. The area in question, on the east-facing coast of the Great Harbour, is the flood-plain of the river Anapus. ${ }^{3}$ The course and mouth of the river may have moved since antiquity (and that of its tributary the Kyane certainly has: it now joins the Anapus at its mouth, but this is the result of modern canalization and it previously joined the Anapus $5 \mathrm{~km}$ from the sea). ${ }^{4}$ From a map, the key question as far as movement on land is concerned would appear to be on which side of the river a given place or group of people is found, but Thucydides does not tell us this clearly. ${ }^{5}$ The initial description of the location of the camp is at 6.66 , where there is again a mention of a $\lambda$ í $\mu v \eta$ (unnamed). It seems natural and economical to agree with K.J. Dover that this is the same lake or marsh which is called Lysimeleia at 7.53. As Dover

\footnotetext{
${ }^{1}$ Homeric features include the extended catalogue of forces (7.57-58); the account of the episode at the river Assinarus (7.84-85) brings to mind the Scamander choked with corpses; the closing claim that the episode

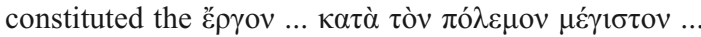

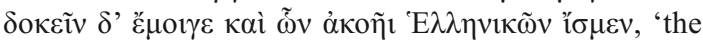
greatest action during this war ... and in my opinion also the greatest of all Hellenic actions of which we know by report', constitutes an implicit comparison with the Trojan War, especially when seen in tandem with the similar claim about the war as a whole made at 1.21, immediately after the introductory survey starting from Troy. On Homeric qualities of the end of book 7, see Allison (1997); Hornblower (2011) 2-3 suggests the need for a study of Homer and Thucydides.

2 The same Iliadic fight by the ships is alluded to in Herodotus' account of Marathon (note the fire at 6.113-
}

14): see Pelling (2013) 9-10. As JHS's anonymous reader suggests to me, this may function here in Thucydides as an intermediate intertext, suggesting the danger that the Athenians themselves, as invaders, may be defeated as the Persians were - but escape for the time being. For a different instance of allusion to this episode in the Iliad, with rich play on audience knowledge of the target text, see Bacchylides 13.141-69 with Fearn (2007) 120-43.

3 See the map in Hornblower's commentary: (19912008) iii.490; for more maps and discussion of topography, see Dover (1970) 466-84.

4 Dover (1970) 479.

5 At 6.66.2 a bridge is destroyed, but subsequent events do not seem to make sense on the basis that the river is uncrossable; perhaps there were other bridges or fords further upstream. At 7.78.2 there seems to be a ford, but it is not very clear where. See Dover (1970) 483 
shows, placing the lake - and thus the Athenians' camp - either north or south of the river causes problems. He may well be right to reach the conclusion that the camp by the $\lambda$ í $\mu v \eta$ was immediately to the north of the mouth of the Anapus. ${ }^{6}$

More generally, in Thucydides' treatment of Syracuse he is very selectively informative about topography, and sometimes writes as if for an audience which has some knowledge of the city and its territory, whether because some aspects of the story of the expedition had already become known among Athenians or (perhaps more importantly) because of the rhetorical impression of knowing expertise which could be communicated in this way. This explains some of the difficulties of working out the geography described above, and is seen more clearly in places such as this: '... and having established a garrison at Labdalon, the Athenians moved towards Syke, where they settled and fortified the Circle rapidly' (6.98). Syke - or even, without the (modern) capitalization, 'the fig-tree' - is nowhere else mentioned, and 'the Circle', also not previously mentioned, is important in the story: the main Athenian camp away from the shore. Yet Thucydides mentions 'the Circle' for the first time as if he were addressing an audience which already knew that such a thing had existed and only fixes it topographically with reference to Syke, whose location has not been specified. ${ }^{7}$ Presumably many readers were unaware of such topographical information; some others probably had partial knowledge of the topography of the fighting and the experience of Athenians in the expedition from the small number of survivors who escaped captivity. ${ }^{8}$ In any case, as we shall see, Lysimeleia is mentioned in only one other place in surviving Greek literature, at Theocritus 16.84: this place is of considerable interest in other ways, but tells us little about topography.

Why did Thucydides name the $\lambda i ́ \mu v \eta$ only on its second occurrence? Perhaps the detail is held back until it is most significant: but why is it significant here? ${ }^{9}$ Part of the answer may be to do

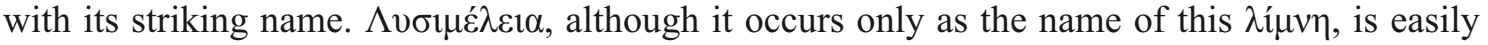
etymologized, and would have communicated an etymological sense readily enough in Thucydides' time. It is closely related to the adjective $\lambda v \sigma \mu \varepsilon \lambda \eta \dot{\zeta}$, of which the initial, verbal component is from

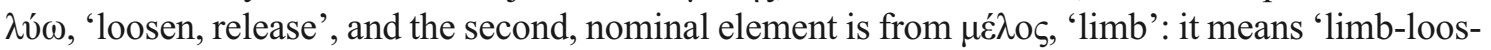
ening'. ${ }^{10}$ This adjective occurs fairly frequently in early poetry, in Homer of sleep and elsewhere of debilitating emotions; the first place I have found where it is used to qualify $\theta \alpha$ ó $\alpha \tau$ cos, 'death', is at Euripides Suppliants 47 (but there were others: Aelian De Natura Animalium 4.41.11 tells us that poets like to call death $\lambda v \sigma \mu \varepsilon \lambda \eta \dot{s}$ because it resembles sleep - i.e., the Homeric association with sleep is considered to be primary, but the use of the adjective to describe death must have been more frequently attested in canonical authors than our evidence shows). ${ }^{11}$ Closely related, both in etymology and in sense, is the Homeric formula $\lambda \tilde{v} \sigma \varepsilon \delta \dot{\varepsilon} \gamma v \tilde{\imath} \alpha$ ('[he] loosened his limbs'), describing the moment of death. ${ }^{12}$ This picture, however, is slightly complicated by the existence in antiquity of a persistent folk-etymology by which the second element of the compound was associated with the stem of the verb $\mu \varepsilon \dot{\lambda} \lambda \omega$, 'I care about or am an object of care'; this was available already in the Odyssey, where at both 20.56 and 23.343 the word $\lambda \nu \sigma \mu \varepsilon \lambda \eta \dot{n}$ (qualifying

${ }^{6}$ Dover (1970) 483-84. The lake/marsh may have extended some distance to the north of this: see, for example, the New Pauly article s.v. Syracusae by LindaMarie Günther (with map).

${ }^{7}$ Cf. Hornblower (1991-2008) ad loc., citing Dover.

8 These were presumably among Thucydides' informants; Plutarch Nicias 30 gives a vivid account of the early dissemination of the news in Athens. On the (limited) role of military travel as a source of information about other places, see Lewis (1996) 35-38 (with the example of the Sicilian Expedition at 36-37).

9 For the technique of delaying information until it is most relevant, see Fraenkel (1950) 3.805 appendix A; for the same technique in Thucydides, Rood (1998) index s.v. 'delay, narrative'.

${ }^{10} C f$., for example, $\lambda v \sigma i \zeta \omega v o \varsigma$, 'girdle-loosening'; $\lambda v \sigma i ́ \pi$ ovo $\varsigma$, 'releasing from toil': Chantraine (2009) s.v. $\lambda v ́ \omega$.

11 Homeric uses of sleep: Odyssey 20.57, 23.343; of eros: for example, Hesiod Theogony 121, 911; Sappho 130.1 L-P.; of $\pi$ ó $\theta$ os, 'yearning': Archilochus 196.1, Alcman 3.61. Later uses associated with death: $A P$

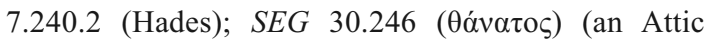
epitaph, second century BC: the only epigraphic usage I have found).

12 Seven times in the Iliad, first at 4.469 . 


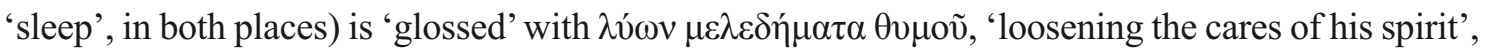
and is also found in the later commentary tradition. ${ }^{13}$ Probably either sleep or death, therefore, could have been perceived at least by some as either 'limb-loosening' or 'care-releasing'. The use of the adjective with eros and $\pi$ ó $\theta$ os shows that this etymology is false (erotic desire and longing for what is absent would not have been said to be 'care-releasing' - quite the contrary), but it may be that, at the time when the lake was named (i.e., at the time of the foundation of the colony, dated to $734 / 3$, or soon afterwards?), as for Thucydides' readers, both interpretations were available.

In any case, the etymologically 'correct' sense 'limb-loosener' suggests itself to Thucydides' readers in this passage: the Etruscans fall upon Gylippus' troops, turn them and drive them into the lake - and, as at the death of a Homeric warrior, their limbs are loosened. This is another respect, then, in which the narrative of this part of the Histories is subtly heightened by evocations of the poetic tradition and may be one reason why the lake is named here, where its name is especially apposite, but not at its previous mention when the Athenians first camped close to it.

\section{Lysimeleia: a holy lake of the 'two goddesses'?}

Why, though, was the lake called by this name, and what can be said about it? As we have seen, there is no other place called by the same name known to us, and it is named only here and in Theocritus. In order to try to understand the name and nature of Lysimeleia, we should consider the Theocritean passage. Theocritus 16, transmitted under the title Xá $\rho \imath \varepsilon \varsigma$ ì 'I $\varepsilon^{\prime} \rho \omega v$, 'The Graces or Hieron', is an encomium addressed to Hieron II of Syracuse (r. 275/4-216/5), probably dating from the early years of his long reign: a poem by a Syracusan for a Syracusan. ${ }^{14}$ The earlier part of the poem is occupied with extensive reflections on the relationship between wealth, poetry and commemoration, rich in reminiscences of Pindar and with explicit use of Simonides as an exemplum. Then the narrator considers whom he should praise of those now living, and presents Hieron as one who will be a great warrior, and is feared by the Phoenicians. He then prays for victory by Hieron and the Syracusans, addressing Zeus, Athena and Kore (named as patroness of Syracuse along with her mother, Demeter), before turning to the blessings of subsequent peace:

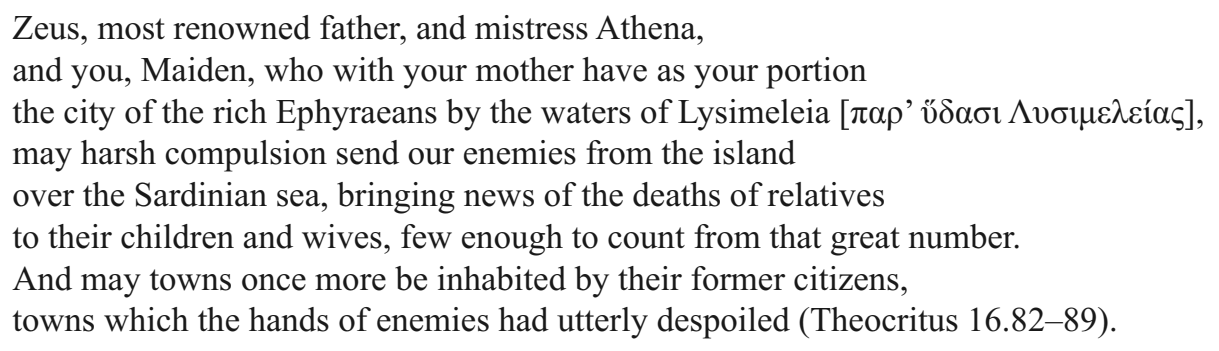

This passage involves rather close reworking of Pindar's first Pythian ode, addressed to Hieron's earlier namesake: ${ }^{15}$

Zeus Accomplisher, determine such good fortune as this always for the citizens and their kings by Amenas' water [A $A \varepsilon \dot{v} v \alpha \pi \alpha \rho$ ' v́ $\delta \omega \rho$ ] to be the true report of men. For with your help a man who is ruler and instructs his son can in honouring his people turn them to harmonious peace. I beseech you, son of Kronos, grant that the war-cry of the Phoenicians and Etruscans may remain quietly at home, now that they have seen their aggression bring woe to their fleet before Kyme, such things did they suffer when overcome by the leader of the Syracusans, who cast their youth from their swiftly sailing ships into the sea and delivered Hellas from grievous slavery (Pindar Pythian 1.67-75, tr. Race, Loeb).

13 For example $\Sigma$ Hesiod Theogony $121 ; \Sigma$ Odyssey 4.794; Eustathius Comm. ad Il. 3.601.7; Nonnus Dionysiaca 42.345 clearly derives from this tradition.
14 On the date of the poem, see Gow (1950) introduction to his commentary; Hunter (1996) 82-87.

15 Cf. Gow (1950) on 16.82; Hunter (1996) 84-86. 
Theocritus changes the chronological relationships: his Hieron's victories are still in the future (presumably because the poem was composed early in the king's reign), but he is to be a king worthy of his name. Pindar combines reference to Hieron's role as king of Syracuse with his role as founder of Aetna, on the river Amenas. Theocritus departs from his model both in the addition of the two goddesses, Kore and her mother Demeter, and in the want of mention of Aetna. In place of the geographical marker identifying Aetna, Syracuse, the city of the Ephyraeans, ${ }^{16}$ is described in terms of its patron goddesses and by reference to the $\lambda$ í $\mu v \eta$ to the south of the city. Given the importance of the worship of the two goddesses at Syracuse and on Sicily more broadly, ${ }^{17}$ and the juxtaposition and close association of the lake with them in Theocritus' text, it seems likely that the lake Lysimeleia was associated in particular with Demeter and Kore. If so, we may wonder whether the name is associated with the sacred qualities of the lake: it might be a good explanation for the name 'Limb-Loosener' if the lake were linked with sacrifice or with death more broadly (the alternative interpretation of the name as 'releaser from care' seems much harder to make sense of as the name of a lake or marsh).

For a lake to be sacred to Demeter and Kore seems likely, since the worship of the two goddesses can be closely associated with a lake elsewhere in the territory of Syracuse:

Like the two goddesses whom we have mentioned [i.e., Athena and Artemis], Kore, we are told, received as her portion the meadows round about Enna; but a great fountain [ $\pi \eta \gamma \eta$ ] was made sacred to her in the territory of Syracuse and given the name Kyane. For the myth relates that it was near Syracuse that Pluto effected the rape of Kore and took her away in his chariot, and that after cleaving the earth asunder he himself descended into Hades, taking along with him the bride whom he had seized, and that he caused the fountain named Kyane to gush forth, near which the Syracusans each year hold a notable festive

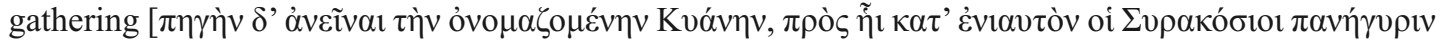
$\dot{\varepsilon} \pi \iota \varphi \alpha v \tilde{\eta} \sigma v v \tau \varepsilon \lambda \sigma \tilde{\sigma} \sigma]$; and private individuals offer the lesser victims, but for public sacrifices they plunge

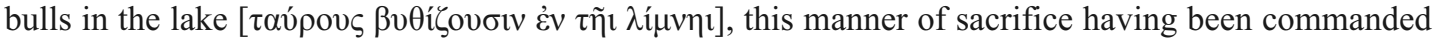
by Heracles on the occasion when he made the circuit of all Sicily, while driving off the cattle of Geryones (Diodorus Siculus 5.4.2, tr. after Oldfather, Loeb).

Is the lake associated with the spring Kyane by Diodorus then the same lake as the one called Lysimeleia by Thucydides and Theocritus? Diodorus' phrasing tells against this. The whole of what he describes is 'near Syracuse', but within that general localization the panegyris is described as taking place $\pi \rho \grave{\varsigma} \varsigma[\tau \tilde{\eta} 1 \pi \eta \gamma \tilde{\eta} 1]$, 'beside the spring', and it is as part of this gathering that the immersion sacrifices take place in the $\lambda i \mu v \eta$. It is possible to imagine that, since Diodorus wishes to connect the myth (associated with the spring) with the ritual (associated with the lake) as closely as possible, he has exaggerated the degree of geographical connection between them, but this is special pleading: it appears from his account that the $\pi \eta \gamma \eta$ and the $\lambda \dot{i} \mu \nu \eta$ are topographically contiguous or closely associated with one another (or even, perhaps, that the two words describe essentially the same geographical feature: a spring feeding directly into a lake). ${ }^{18}$ Accordingly, Lysimeleia, situated by the coast of the Great Harbour, is too far away from the source of the river Kyane to be the $\lambda \dot{\mu} \mu \nu \eta$ described by Diodorus. ${ }^{19}$ So there are, by my argument, two holy lakes

16 i.e. a Corinthian colony: $c f$. Theocritus 15.91 , 28.17-18. For the Sanctuary of Demeter and Kore on the Acrocorinth and colonization, see Bookidis (2008).

17 For the importance of the two goddesses to Sicily, see Bacchylides 3.1; Pindar Pythian 12.3, Nemean 1.1318; $\Sigma$ Pindar Olympian 2.15 (i.62 Dr.); Diodorus Siculus 5.1.3 (and his attention to Demeter and Kore in subsequent sections of the same book, some of them discussed below). For studies of Demeter and Kore on Sicily, see Hinz (1998); De Miro (2008); Schipporeit (2008), Sfameni
Gasparro (2008). Sfameni Gasparro (1986) treats myth and cult relevant for our purposes, especially part 2 , chapter 1 .

$18 C f$. Pausanias' account of the spring of Amphiaraus and lake of Alkyone at Lerna, where the two appear to be very closely associated topographically (Pausanias 2.37.5).

${ }^{19} \mathrm{Cf}$. the discussion of geography above, section II. For attempts to identify archaeological traces of the sanctuary by the source of the Kyane, see Hinz (1998) 102; De Miro (2008) 68. 
associated with the two goddesses: one close to the source of the Kyane, attested in Diodorus, and another (Lysimeleia) by the shore of the Great Harbour close to the mouth of the Anapos.

Here in Diodorus we have a lake in the territory of Syracuse which is sacred to Kore, or perhaps to Kore and Demeter. The spring (or the lake - or perhaps both, as comparative evidence cited below might suggest) is a place of access to Hades, like Acheron. Elsewhere we can find other examples of marshes, lakes and springs as the sites of cult for chthonic deities: for example at Lerna, a place of Dionysiac mysteries, Pausanias (n.18) saw the spring of Amphiaraus and the Alkyonian $\lambda i ́ \mu \nu \eta$, where Dionysus went to Hades for Semele; in the territory of Pheneus in Arcadia, myth associated Demeter with the waters of the Styx (it is unclear what this reflects in terms of cult). ${ }^{20}$ At Hermione, Demeter was worshipped under the cult title Thermasia, which should have to do with the proximity of hot springs. ${ }^{21}$ Indeed, the complex of cults at Hermione has other suggestive parallels (Pausanias 2.35.10, where - as Pausanias effectively tells us - Klymenos is part figure of epichoric myth/cult, part local cult title of Hades, and Chthonia can likewise name Klymenos' sister or can serve as a cult title of Demeter):

Behind the temple of Chthonia are the places which the Hermionians call 'the place of Klymenos', 'the

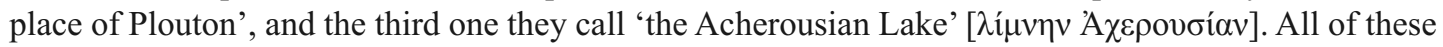
are enclosed by stone walls, and in the place of Klymenos there is a opening in the earth. Through this Heracles brought up the dog of Hades, according to the stories of the Hermionians.

So here we see a rather similar combination of an opening in the ground perceived as a place of access to Hades (as was the Alkyonian lake at Lerna) and a $\lambda$ í $\mu v \eta$, here in name only and called after the famous lake of the river Acheron. If, as seems likely, these enclosures functioned as places of sacrifice, the sacrifices at the 'Acherousian Lake' are a symbolic enactment of sacrifice by immersion in water: the same which occurred in practice in the ritual described by Diodorus. This may be the result of a specific connection between the religious practices of Hermione and Syra-

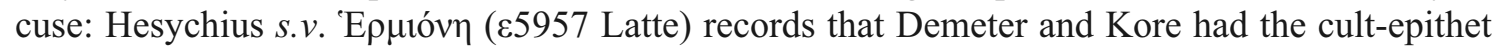
Hermione at Syracuse. ${ }^{22}$

A further question remains, i.e. whether either of these lakes in the territory of Syracuse (Lysimeleia and the lake by the spring Kyane) is identical to the lake Syrako, mentioned by Stephanus

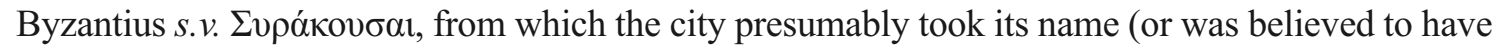
done). ${ }^{23}$ This seems to be unanswerable on the evidence of which I am aware, but Theocritus' use of the name Lysimeleia in a periphrasis for the city of Syracuse ('the city of the rich Ephyraeans by the waters of Lysimeleia') (83-84) would have special point if the same lake were also known by the name from which the city itself had been called. Further, it is not obvious why the city of Syracuse should be named after a lake at all, given its location: the spring Arethusa and the island of Ortygia, for example, both seem like more obviously important topographical features as far as the astu is concerned; but if the lake in question were the site of shared cultic activity of significance for the self-definition of the polis, this would make better sense. If this speculation is pointing in the right direction, it would suggest that at least in the early history of the colony the perceived importance

${ }^{20}$ Photius Bibliotheca 190 (148a Bekker), from Ptolemy the Quail: escaping the attentions of Poseidon, Demeter transformed herself into a mare, and upon seeing her reflection in the waters of the Styx she turned its waters black. See Jost (1985) 324, who comments that the truncation of the story in Photius has deprived us of its connection with local cult ('coupé d'un sanctuaire qui l'aurait maintenu en vie') and provides other evidence for the association of Demeter and the Styx.
${ }^{21}$ Pausanias 2.34.6, 2.34.12: note the position of the former sanctuary beside the sea. On the cultic geography of Hermione, see Prauscello (2013).

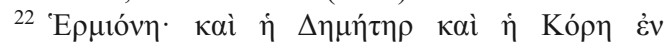

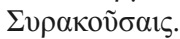

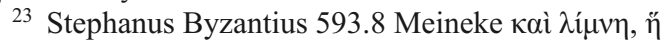

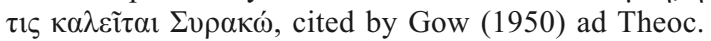

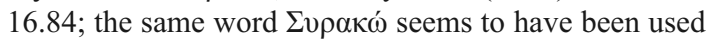
as an alternative for the name of the city (Strabo 8.5.3 Epicharmus fr. $231 \mathrm{KA}$ ). 
of Lysimeleia in the life of the city was considerable - but it should be emphasized that it is not certain whether Lysimeleia should be identified with Syrako, even though reducing three apparently significant lakes in the chora of Syracuse to two might seem satisfyingly economical.

Given what we know from Diodorus about the $\lambda i \mu v \eta$ at the spring of Kyane, comparative evidence for springs and lakes associated with chthonic deities as places of sacrifice and of access to the underworld, and the name Lysimeleia, the 'loosener of limbs', it is tempting to make a further inference: that Lysimeleia was so-called because it too was a lake used for immersion sacrifice by driving animals into its waters or at least that it was the location of sacrifice to Demeter and Kore and that its waters were treated in myth and/or cult as deathly waters, as at the lake of Acherousia and at Kyane.

\section{Back to Thucydides 7.53}

With these features in mind, we can return to the passage of Thucydides from which we started

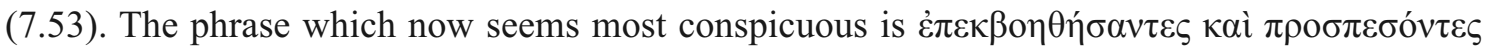

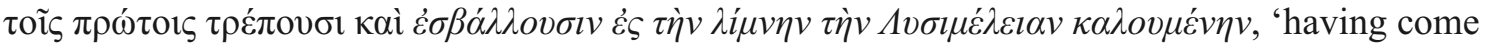
out to help, [the Etruscans] attacked the leaders, turned them, and drove them into the lake called Lysimeleia'. The verb $\varepsilon i \sigma \beta \alpha \dot{\lambda} \lambda \lambda \omega$, while not at all out of place in a military context, is also regularly used of driving animals. ${ }^{24}$ In the light of our researches into Lysimeleia, sacred lakes and their connections in Syracuse with immersion sacrifice, it might seem that Gylippus' men are taking the place of animal victims in a grim perversion of the proper sacrificial rites to the twin goddesses. This would be especially the case if immersion sacrifice was practised at Lysimeleia as at Kyane; however, the combination of the lake's name and the knowledge that it was sacred to the twin goddesses with the account of the unpleasant fate of the drowned soldiers would probably be enough to evoke similar resonances even if the cult practices there were in fact different from those at Kyane (especially if a reader were well-informed about other aspects of the cult of the two goddesses in Syracuse). ${ }^{25}$

The possibility of reading the actions described here in the knowledge of (what I have argued as) the sacred quality of the lake should be read against other aspects of the passage which may hint at possible 'religious' significance. Both S. Hornblower and T. Rood have drawn attention to a pattern by which characters in Thucydides who hope to achieve something 'easily' tend to be disappointed; and, truly enough, Gylippus' plan, by which he hopes that the Syracusans might tow away the Athenians' ships 'more easily [ $\dot{\rho} \tilde{\alpha} ı v]$ ' is unsuccessful. ${ }^{26}$ But this pattern overlaps with an emphasis on contingency and small-scale reversal of fortune which mirrors the broader context: that the Athenians' small, temporary success makes no difference to the overall movement towards Athenian disaster. I have already mentioned the repetition of compounds of $\beta$ $\eta \theta \varepsilon$, 'help', as something which draws attention to reversals of fortune within this brief episode. Another feature, again mentioned by Hornblower, is wind-direction. He suggests that ' $[\mathrm{w}] \mathrm{e}$ are reminded that the

${ }^{24} \operatorname{\varepsilon i\sigma } \beta \alpha \dot{\alpha} \lambda \lambda \omega$ with animals as object and with sic as here: Herodotus 2.14; Euripides Electra 79; with double accusative Euripides Iphigeneia in Tauris 260-61 (driving cattle into the sea - for a bath: $c f .254-55$ ); $c f$. $I G$ 12.1.677.31 (Ialysus, Rhodes, 'not after 3rd c. BC': a prohibition against driving animals into the sanctuary). These references all from LSJ s.v.

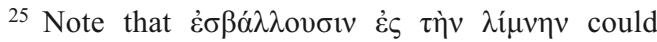
convey either 'drove them into the lake' or 'drove them to the lake', and that the latter could apply to sacrificial victims even if the custom were to kill them by the lake rather than actually in it.

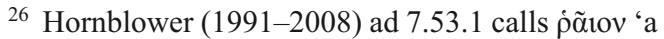
warning ... that things will go wrong' (i.e. will go wrong for Gylippus) and refers to Rood (1998) 34, n.30 for this observation and for the comment 'Only gods do things with ease' and the reference to Homeric passages including Iliad 15.361-66 (Apollo destroys the Achaeans' fortification as easily as a child destroys sandcastles by the sea): given the context of this Homeric place at the start of the battle by the ships and the way in which this corresponds to the situation at Syracuse (see above, at n.2), one might read it as a special intertext here, but if this seems rash it is in any case the underlying pattern of thought which is important. Rood in his turn cites Hornblower (1991-2008) ad 2.3.2. 
outcome is not unavoidable, even now. This "contingency" is lightly underlined by parenthetical narrative statements about wind-direction - a sort of minor epiphany, on a worldview not obtrusively evident in Th. - as at para. 4 [i.e. 7.53.4] below'. ${ }^{27}$ This observation can be developed with regard to the present chapter, where the Athenians first flee from the sea-battle towards the shore, where Gylippus' attempt on their camp has failed, 'saving' all but 18 of their ships. At this point, the Syracusans attempt to destroy the Athenian ships by use of a fire-ship, and Thucydides notes

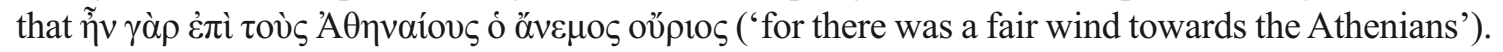
In other words, the wind was blowing on-shore (from the east). Thucydides does not explicitly say so, but for the reader who is visualizing the battle, this embodies a rapid reversal of fortune. The Athenian ships, having been defeated, have had a wind which was fair for them, i.e. which made it much easier for them to escape to their camp and protected mooring-place (as they fled they had the wind at their backs). They will have believed that this same wind gave no advantage to the Syracusans for as long as they were in their protected harbour, which it seems clear that the Syracusans could not penetrate. ${ }^{28}$ But as soon as the Syracusans devise their fire-ship, what had seemed a fair wind for the Athenians becomes a fair wind against the Athenians. So first there is a pattern by which Thucydides' account might for some readers suggest a traditional/moral/religious way of conceiving of Gylippus' failure at Lysimeleia (he wanted things to be easy - but only for gods are things easy); then we see the moment when a fair wind for the Athenians, which many might have interpreted as a mark of divine assistance ('a sort of minor epiphany', as Hornblower puts it) becomes the opposite, a fair wind for the Syracusans' fire-ship plan. ${ }^{29}$ So despite the characteristic unwillingness of the Thucydidean narrator (on this, see further below) to draw attention to the possibility of 'religious' interpretations, here he nevertheless seems to place the driving of Gylippus' men into Lysimeleia in a context which offers a rather rich variety of possibilities for such interpretation, and to describe it using vocabulary which may hint inexplicitly at the kind of significance for which I have argued.

The narrator, in any case, does not explore the possible significance of Lysimeleia explicitly, and this is clearly in keeping with Thucydides' well-known tendency to avoid overt discussion of religion or the gods. ${ }^{30}$ For a contrasting example of a historical treatment of battle at a place sacred to Demeter, we could compare Herodotus' account of the fighting around that goddess' sanctuary at Plataea (9.65): Herodotus records that none of the Persians died in the sanctuary itself, but rather around it, and diffidently suggests that the goddess refused to admit those who had fired her temple at Eleusis. It was evident to Herodotus (and, we may suppose, to many of his contemporaries) that the fact of fighting around the grove of the goddess was significant and that an account of what happened had to pay attention to it. Thucydides is more unconventional and partial, and his response to the importance of religion in his own world, and to the religious meaning of the landscape in which the events narrated take place, is at least largely one of suppression. Thus, in a work in which two long books are devoted largely to events in Sicily, the two goddesses with whom the island was especially associated are never mentioned by name.

However, as with the mention of wind-direction and the 'easy' motif described by Hornblower and mentioned above, we should not discard the possibility that this Thucydidean passage is capable of being interpreted in a way which might pay attention to the religious significance of our putative holy lake of Demeter.

27 Hornblower (1991-2008) ad 7.53.2.

${ }^{28}$ Both sides successfully employ palisades to protect their own harbours $(7.25,7.38$, and $c f$. the use of है $\sigma \omega \sigma \alpha \nu$ in the present chapter: the harbour is a place of safety) and the Athenians also use block-ships with 'dolphins' (7.38, 7.41).

${ }^{29}$ For winds as divine intervention in historical battles, $c f$. the role of Boreas in the storm before the
Battle of Artemisium (Herodotus 7.189, where Herodotus declines to pass judgement on the truth of the Athenians' story; $c f$. Simonides $f r .3 \mathrm{~W}^{2}$, at any rate if Kó $\lambda \alpha_{1}[v$ is the correct reading at 3.5).

30 See especially Hornblower (1992), now revised and reprinted, with an introductory caveat relevant to my present argument, at Hornblower (2011) 25-58. 


\section{What Thucydides does not tell us: religious interpretations of the Athenian invasion of Sicily}

If Lysimeleia was a holy lake associated with the two goddesses, this must have been apparent to members of the Athenian force at Syracuse, whether because its sacred quality was apparent on the ground from buildings or dedications or the like (the area had 'walls and houses' 6.66) or because of local knowledge passed on by spies and captives. Some of them will have been impressed by the lake not only by virtue of its utility in protecting approaches to their camp (as outlined by Thucydides at 6.66) but also because of its sacred qualities, and their view of what happened when their Etruscan allies drove the enemy vanguard into the lake will have been coloured accordingly.

It is possible to imagine an optimistic interpretation, by which Demeter was on their side, helping to protect the camp. But this seems unlikely, given the impression we have from Thucydides that the condition of the expeditionary force was already poor at this time and their morale must have been low - and even if such an interpretation carried some force initially, it would not have survived the expedition's eventual destruction, after which it was the Athenians' failure which needed to be explained and described. More probably, the fact that their allies had driven men into the goddesses' lake would seem troubling: they profaned the lake with a disturbing, unholy parody of sacrifice, in an offence against the local cult from which adverse consequences could be feared and expected. A different kind of narrative from Thucydides', told by somebody less dismissive of (for example)

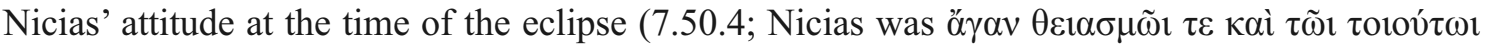
$\pi \rho \circ \sigma \kappa \varepsilon i ́ \mu \varepsilon v o \varsigma$, 'excessively inclined to pay attention to prophecy and the like'), would have been willing to admit more explicitly the possibility of an account of the Sicilian Expedition which included religious elements and took them seriously as a part of the story of the Athenian disaster. Such a story would have been told and heard in a way which acknowledged the inseparable connection between a polis and its religious activities and spaces, and the associated moral-religious danger associated with invasion. ${ }^{31}$ The Athenian attack on Syracuse and its territory would always have been potentially interpretable as an attack on its gods and sanctuaries, and its landscape, like that of any polis, would have been well-supplied with sacred places - places which are being trampled by an invading army. ${ }^{32}$

Lysimeleia and the significance of Demeter and Kore to the religious identity of Sicily in general and Syracuse in particular would also have had more specific resonances because of the importance of the two goddesses in Athenian religion, above all at Eleusis. Despite the difficulties of extrapolating the position in the fifth century from later sources, Sicilian mythology of the two goddesses could have been perceived as a rival to the mythology promoted at Eleusis. Diodorus' account of the rape of Kore from the territory of Syracuse, given above, continues as follows:

After the rape of Kore, they tell the story that Demeter, being unable to find her daughter, lit torches in the craters of Aetna and visited many of the places in the inhabited world, and that she gave benefactions to the people who especially welcomed her by giving them in return the fruit of the wheat. And since the Athenians received her in an especially generous way, she gave them the fruit of the wheat first after

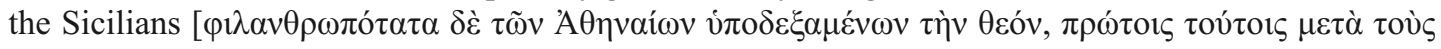
$\Sigma ı \kappa \varepsilon \lambda \iota \dot{\tau} \tau \alpha \varsigma \delta \omega \rho \eta ́ \sigma \alpha \sigma \theta \alpha \imath \tau \grave{v} v \tau \tilde{\omega} v \pi v \rho \tilde{\omega} v \kappa \alpha \rho \pi$ óv]. In return, this people honoured the goddess to a more remarkable degree than others, with especially famous sacrifices and with the mysteries at Eleusis, which by their antiquity and holiness became the talk of all mankind. Many people received the gracious gift of wheat from the hands of the Athenians, and by sharing the seed with their neighbours they filled all the known world (Diodorus Siculus 5.4.3-4, tr. after Oldfather, Loeb).

31 For the intimate relationship between religious activities and the polis, see above all Sourvinou-Inwood (2000). For the dangerous possibility that to attack a city is to attack its gods and holy places, see, for example, Euripides Phoenician Women 603-09; Troades 95-97; and see further below. For the 'divine guarantee' to the polis (which may be withdrawn), see Sourvinou-Inwood (2000) 23-24.
32 For comparison, one may reflect on the very large number of sanctuaries, cult-places, even sacred olive trees scattered among the demes of Attica. Any warfare taking place in the Attic countryside will have involved a high likelihood (almost a certainty) of actions which could count as desecration of sacred space. 
There follows an account of the festivals of Demeter and Kore among the Sicilians, in which it is repeated that the reason for this was the intimate connection of the goddesses with the island

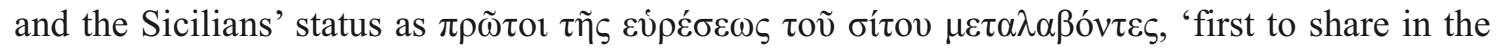
discovery of corn'. Superficially, Diodorus (or his source) is trying to reconcile the local mythology of Syracuse and of Sicily with the Eleusinian myth, and since it seems that the outline of the Sicilian story is close to that known since the Homeric Hymn to Demeter, this was not as difficult as it might have been. ${ }^{33}$ However, it seems that this reflects an earlier Syracusan myth which was irreconcilable with, although similar to, the Athenian-Eleusinian account: the Athenians claim that it was at Eleusis that Demeter had first given mankind the gift of wheat. ${ }^{34}$ We know that this claim was important to Athenians in the later fifth century, since we have an inscription which records the Athenians' invitation to other poleis to send offerings to Eleusis. ${ }^{35}$

So some Athenians would have perceived Sicilian traditions both as similar to their own and as competitors with the claim of Eleusinian primacy. One may wonder whether propaganda associated with the Sicilian Expedition involved asserting the primacy of the Athenian cult against its colonial rival; there is, as far as I know, no evidence for such a thing, but again it is the kind of story which Thucydides would not choose to tell us. If so, the idea that the Athenians' Etruscan allies had desecrated the holy lake at Lysimeleia and offended Demeter and Kore might have been all the more disturbing from an Athenian point of view - or all the more morally satisfying from the point of view of the Athenians' enemies, who could see their attempt to impose their own variant of the myth on others and to claim a pan-Hellenic status for it by the exercise of their financial and military power as religiously offensive to the goddesses they claimed to revere.

Irrespective of whether the Athenians made propagandistic use of the relationship between Eleusinian mythology and corresponding stories on Sicily, if the Athenians were seen to be profaning the lake sacred to the two goddesses in the chora of Syracuse, this would have uncomfortable broader resonances in the context of the larger set of conflicts which Thucydides describes. Friends and foes of the Athenians would have related Athenian offences against the goddesses in Sicily to the alleged offences of the Megarians against the sacred land of the same goddesses in the plain around Eleusis, which were part of the (ostensible) reason for the 'Megarian decree' - a piece of religious argumentation which Thucydides does not consistently conceal, and of which his readers were of course fully aware (not least since sources other than Thucydides regularly ascribe a higher importance to it than he did). ${ }^{36}$ To perceive the Athenian forces in Sicily as desecrators of a site sacred to the two goddesses is likely to provoke the thought that their charge against the Megarians seems hypocritical, and perhaps cynical (as it surely was).

\footnotetext{
${ }^{33}$ Enna also claimed to be the site of the rape of Kore: Diodorus Siculus 5.3.1-3. Cicero In Verrem 2.4.48§107 shows an attempt to reconcile these competing claims within Sicily. For Quellenkritik of Diodorus and Cicero on this matter, see Schipporeit (2008) 43-45, with references to earlier treatments.

${ }^{34}$ Literary sources are bitty: see Gantz (1993) 6970; Graf (1974) 158-81. Triptolemus on a chariot with ears of grain, with Demeter, is depicted on Athenian painted pottery from the time of Exekias (i.e. ca. 550 $530 \mathrm{BC}$ ) onwards, which presumably reflects Eleusis as the location of the gift of grain to mankind: Gantz (1993) 70; $c f$. Furley (1996) 35.

${ }^{35} \mathrm{ML}^{2} 73=I G \mathrm{I}^{3} 78$ a 30-36. Cf. Hornblower (1992) $186=(2011) 41-42$; Furley (1996) 35-37. The inscription is hard to date: see Meiggs and Lewis (1988) ad loc. for possibilities, which seem to range from the 430 s into
}

the $410 \mathrm{~s}$. Hornblower and $I G \mathrm{I}^{3}$ both suggest (tentatively) a date in the 420 s. Furley's argument, to the effect that the inscription and cult are symbolic of peace and its blessings, and that the profaners of the Eleusinian Mysteries in 415 (including Alcibiades) were hostile to Eleusis for that reason, leads him to favour a date as late as 415 . For the enduring importance of the claim in the fourth century, $c f$. Isocrates 4.28-33.

36 Thucydides tells us at 1.139.2 that the Athenians charged the Megarians with $\dot{\varepsilon} \pi \varepsilon \rho \gamma \alpha \sigma i \alpha \nu \ldots \tau \tilde{\eta} \varsigma \gamma \tilde{\eta} \varsigma \tau \tilde{\eta} \varsigma$

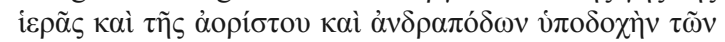

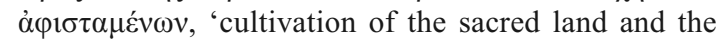
unmarked land and harbouring runaway slaves', but previously (at 1.67) he had reported the Athenian embargo without explaining the alleged reasons for it. See Lewis at $C A H^{2}$ V. 370-78 with further bibliography. 
Perhaps most obviously, all members of the expedition and all of Thucydides' first audience knew that the story of the Sicilian Expedition, like the story of the Iliad, began with conflict concerning offence given to a god, or rather two goddesses, as a result of the revelation not only of the mutilation of the Herms, but also of the sacrilegious profanation of the mysteries at Eleusis. ${ }^{37}$ Doubtless Thucydides was right to report that one of the reasons why this was considered so troubling was that it was perceived as a form of conspiracy against the democracy (6.28.2). Certainly he does not encourage the reader to reflect that the offence against Demeter and Persephone was revealed, troublingly, immediately before the Athenians were about to set out for the island given to Demeter by Zeus, and (by its own traditions) the location of the rape of Persephone. ${ }^{38}$ Modern studies are frequently more interested than Thucydides in the religious significance of the offences, but it remains usual to discuss the profanation of the mysteries without mention of the importance of the same two goddesses on Sicily, ${ }^{39}$ perhaps partly as a reflex of Thucydides' own silence on the matter. But many Athenians will have been aware of the Sicilian connection, and this must have made the discovery of the offences against the two goddesses a particularly bad omen. ${ }^{40}$ Some members of the expedition who viewed the driving of Gylippus' men into the lake as a religiously dangerous act would have made the connection with the revelations which preceded their departure from Athens: perhaps Demeter was against the Athenians from the start and perhaps her enmity is now reinforced at a crucial moment. Again we see the possibility of a narrative different from that given by Thucydides, receptive to different emphases and interpretations. The idea of offence against the two goddesses was there at the beginning of the expedition and is now reprised as a prelude to the final debacle.

\section{Theocritus $16.82-89$ revisited}

We now return to Theocritus, focusing now on how our interpretation of Lysimeleia may help us to read the later text:
Zeus, most renowned father, and mistress Athena, and you, Maiden, who with your mother have as your portion the city of the rich Ephyraeans by the waters of Lysimeleia, may harsh compulsion send our enemies from the island over the Sardinian sea, bringing news of the deaths of relatives to their children and wives, few enough to count from that great number [ $\alpha \rho \rho \theta \mu \eta \tau$ ò̀ $\dot{\alpha} \pi$ ò $\pi \mathrm{o} \lambda \lambda \tilde{\omega} v]$. And may towns once more be inhabited by their former citizens, towns which the hands of enemies had utterly despoiled (Theocritus 16.82-89).

This poem combines many threads of Sicilian history to praise Hieron II, to treat which in detail would be beyond the scope of this paper. In particular, there is a pattern of assimilation between Hieron II and his early fifth-century namesake and his Deinomenid brothers, promoted through the use of Pindar's Pythian 1 as a key intertext. ${ }^{41}$ Should we read the mention of Lysimeleia as further enriching the blend of historical reference in Theocritus' poem? There is a complicating

37 The main texts are Thucydides 6.28 and Andocides On the Mysteries.

38 Given to Demeter by Zeus already at Pindar Nemean 1.13-14; $c f$. n.17 above.

${ }^{39}$ Religious interpretations: for example Furley (1996); fuller bibliography on the mutilation of the Herms and profanation of the mysteries given by Hornblower (1991-2008) 3.367-72 ad 6.27-9. An exception to the tendency to discuss the profanation of the mysteries without reference to the importance of
Demeter and Kore on Sicily is Pelling (2000) 23 (thanking Judith Mossman and Christiane SourvinouInwood in n.13).

40 Some Athenians would have had knowledge about Sicily in general as a result of the expedition of 427-424 (Thucydides 3.86).

41 On Theocritus' use of Pindar, see in particular Hunter (1996); on Pythian 1 as a key text, see Hunter (1996) 84-87. 
factor, since one may suspect that the idea of enemies being sent away over the Sardinian Sea (to the northwest of Sicily) might evoke memories of the Deinomenid victories at Cumae and Himera (on the northern coast of the island), ${ }^{42}$ and the idea that the survivors who brought the news of the defeat were 'countable among many' echoes a tradition reported by Diodorus about the Battle of Himera:

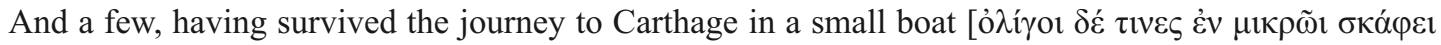

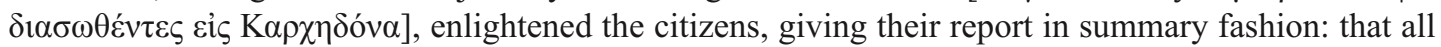
who crossed to Sicily had perished (Diodorus Siculus 11.24.2).

Here, however, this might seem to overlap with memories of an intermediate conflict, in which the Syracusans were again successful in driving out their enemies, and few survived to bring home the news. If the mention of Lysimeleia by Theocritus might have reminded some readers of the episode beside the same lake narrated by Thucydides, the idea that the messengers returned home $\dot{\alpha} \rho \imath \theta \mu \eta \tau$ ò̀ $\grave{\alpha} \pi$ ò $\pi \mathrm{o} \lambda \lambda \tilde{\omega} v$, 'countable from among many', might combine allusion to traditions about Himera with a recollection of the conclusion to Thucydides' account of the Athenian expedition: ${ }^{43}$

This was, as they say, 'total annihilation'. Beaten in every way on every front, extreme miseries suffered on an extreme scale, and army, fleet, and everything else destroyed, few out of all those many [ỏ $\lambda$ í $\gamma o 1$ $\dot{\alpha} \pi \hat{o} \pi \mathrm{o} \lambda \lambda \tilde{\omega} v]$ made their return home. Such were the events in Sicily (7.87.6, tr. Hammond, Oxford World's Classics).

Theocritus' lines, therefore, may evoke the triumph of the Syracusans over the Athenian expedition at the same time as their triumphs over the barbarians: Hieron II's victories will be the latest in a Syracusan tradition of utter destruction of invading enemies, whether Greek or barbarian.

\section{Conclusion}

By way of a conclusion, I return to Thucydides. If we accept the probable case that Lysimeleia was a sacred lake of Demeter and Kore, and that the actions of the Athenians' Etruscan allies in driving Gylippus' men into the lake were interpretable as a profanation of its holy waters by a kind of parody of immersion sacrifice, this is of interest in its own right as a contribution to the understanding of the religious behaviour and sacred geography of Syracuse. But it is also of interest for our understanding of Thucydides' narrative, and how his account of the Sicilian Expedition, whatever its undoubted qualities as history and as narrative, also by means of its selectivity obscures elements of what 'really happened' and was perceived as important by the actors of the story, and equally important elements of the discourse which must have surrounded the events described. It is difficult to tell whether, by referring to the name of the lake, Thucydides actually 'intended' to remind readers of an aspect of the expedition which he generally suppressed or whether we should say that the name allows us and would have allowed earlier readers to guess

42 Cf. Dover (1971) ad 16.86.

43 There might also be an intertextual connection between this Thucydidean passage and the tradition concerning Himera evidenced by Diodorus, as quoted above; it is interesting to note that, when giving a slightly different account of the aftermath of the Battle of Himera, Diodorus tells us (11.23.2) that $\tau$ ò $\delta \grave{\eta} \lambda \varepsilon \gamma o ́ \mu \varepsilon v o v \mu \eta \delta \grave{\varepsilon}$

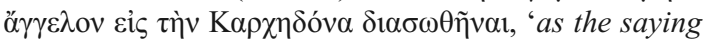
goes, no messenger survived to bring the news to Carthage': this use of $\tau$ ò $\lambda \varepsilon \gamma o ́ \mu \varepsilon v o v$ looks as if it might look back to Thucydides' use of the same phrase (for the sense of which, see Hornblower (1991-2008) ad loc., who argues both that $\tau$ ò $\lambda \varepsilon \gamma$ ó $\mu \varepsilon v o v$ 'may indicate a wider and proverbial range of allusion now lost to us' and that the word marks an allusion to Herodotus 2.120.2, where $\pi \alpha \nu \omega \lambda \varepsilon \theta \rho i$ i 1 is used of the Trojan War). On the Homeric flavour of the last chapters of Thucydides 7, see Allison (1997). ỏ $\lambda$ ífol $\dot{\alpha} \pi$ ò $\pi \mathrm{o} \lambda \lambda \tilde{\omega} v$ also occurs in Thucydides at 1.110.1, 3.112.8 (Hornblower (1991-2008) ad loc.). 
at something which the historical Thucydides would have preferred to occlude altogether, even if we have seen that the context and expression may hint at the possibility of such a way of reading. ${ }^{44}$ In any case, we are reminded that Thucydides' selective way of presenting the events of his own time can conceal much from us. For many of his contemporaries, and for us, questions of religion and of religious interpretation of events might very well have been of the first importance, but the selectivity of Thucydidean narrative obscures this.

We need not choose to view this only as an idiosyncrasy of Thucydides or as a marker of his (in)famous 'rationalism' or receptivity to the philosophical developments of the later fifth century (and in any case we will certainly wish to deny that simply omitting to discuss religious motivations or interpretations is a marker of 'rationalism' in any straightforward way). Rather, we may also wish to consider Thucydides' suppression of religion in comparison with more 'popular' forms of serious discourse about warfare and the invasion of cities. For the tragic poets, the idea of religiously offensive behaviour was an important way in which to explore and make apparent the morally dangerous qualities of warfare: ${ }^{45}$

A fool is that one among mortals who destroys cities, and having given temples and tombs, holy places of those who have died, to desolation, himself perishes after (Euripides Troades 95-97, Poseidon speaks).

Again, one suspects that some could have generated a story of the Athenians' failure which included such religious offences as are outlined in Darius' interpretation of the failure of the expedition of Xerxes:

When they came to the land of Greece, they did not scruple to plunder the images of the gods and set fire to temples: altars have vanished, and the abodes of deities have been ruined, wrenched from their foundations. Because of this evil they have done, they are suffering evil to match it in full measure, and have still to suffer more: the fountain of suffering has not stopped flowing - more of it is still gushing forth, so great will be the clotted libation of slain men's blood on the soil of the Plataeans, shed by the Dorian spear (Aeschylus Persians 809-17, tr. Sommerstein, Loeb).

From passages such as these we can see that for many of Thucydides' contemporaries the language of religion and the idea of offences against sacred places was an important resource for a moral language by which to describe the degeneration of behaviour which can accompany warfare and militarism. The idea of desecration of holy places such as temples and shrines is expressive of the moral/religious danger involved in the invasion of others' land and makes the

\footnotetext{
${ }^{44}$ Our attitudes to this question will doubtless depend on our views about Thucydidean history more broadly. $C f$. section IV, above, for factors such as the attention to wind-direction and the motif by which one who attempts to do something easily is likely to fail, which might lead to the view that this is a place where Thucydides is at least willing to hint at what he will not suggest more explicitly. There is perhaps an analagous problem with a fascinating detail of Thucydidean interpretation at 3.22: the Plataeans make an escape, lightly armed and by night, 'shod only on the left foot, so that they would not slip in the mud'. As Lévêque and VidalNaquet (1986: translation, with addenda, of original 1960 publication) were first to see, this 'rationalizing' explanation conceals a more plausible religious/symbolic meaning of monosandalism (cf. Hornblower (1991-
}

2008) ad loc.; Hornblower (2004) 87-88 for the history of the argument with further bibliography). Yet we should wonder about this: if the Plataeans in 428/7 naturally 'got' the meaning of monosandalism, would not Thucydides have expected his own readers to understand it too and to see through his 'rationalizing' concealment? Perhaps we should rather say that Thucydides, while appearing to prefer a 'rational' (but implausible) explanation, is simultaneously drawing attention to a religious aspect of the story about which he could, after all, have chosen to be silent.

45 This play, first performed in spring 415 , must have been capable of being understood as in part a response to growing militarism in Athens prior to the Sicilian Expedition (whether or not conceived of as a response to the subjugation of Melos a few months previously). 
sacking of cities a morally dangerous act. ${ }^{46}$ The defilement of the lake of the two goddesses could have been an indication of the moral danger involved in the Athenians' misguided expedition and for many of Thucydides' contemporaries would have symbolized not only that the expedition was ultimately doomed, but also that it was doomed in a way which led naturally to a morally inflected interpretation. By his 'rationalism', it may be that Thucydides did not only deprive us of much that we would like to know, but also found a way in which to describe the imperialism of the Athenians in which he removed the source of the most natural and compelling rhetoric by which another might have condemned it.

\section{Bibliography}

Allison, J.W. (1997) 'Homeric allusions at the close of Thucydides' Sicilian narrative', AJPh 118, 499-516

Bookidis, N. (2008) 'The Sanctuary of Demeter and Kore at Corinth and colonization', in C.A. Di Stefano (ed.), Demetra. La divinità, $i$ santuari, il culto, la leggenda (Pisa and Rome) 99-105

Chantraine, P. with contributions by J. Taillardat, O. Masson and J.-L. Perpillou (2009) Dictionnaire étymologique de la langue grecque (Paris)

De Miro, E. (2008) 'Thesmophoria di Sicilia', in C.A. Di Stefano (ed.), Demetra. La divinità, i santuari, il culto, la leggenda (Pisa and Rome) 47-92

Dover, K.J. (1970) = A.W. Gomme, A. Andrewes and K.J. Dover, A Historical Commentary on Thucydides 4 (Oxford)

- (1971) Theocritus. Select Poems (London)

Fearn, D. (2007) Bacchylides. Politics, Performance, Poetic Tradition (Oxford)

Fraenkel, E. (1950) Aeschylus. Agamemnon (3 vols) (Oxford)

Furley, W.D. (1996) Andokides and the Herms: A Study of Crisis in Fifth-Century Athenian Religion (BICS Supplement 65) (London)

Gantz, T. (1993) Early Greek Myth. A Guide to Literary and Artistic Sources (Baltimore)

Gow, A.S.F. (1950) Theocritus (Cambridge)

Graf, F. (1974) Eleusis und die orphische Dichtung Athens in vorhellenistischer Zeit (Berlin and New York)

Hinz, V. (1998) Der Kult von Demeter und Kore auf Sizilien und in der Magna Graecia (Wiesbaden)

Hornblower, S. (1991-2008) A Commentary on Thucydides (3 vols) (Oxford)

- (1992) 'The religious dimension to the Peloponnesian War, or, what Thucydides does not tell us', HSPh 94, 169-97

- (2004) Thucycides and Pindar: Historical Narrative and the World of Epinikian Poetry (Oxford)

- (2011) Thucydidean Themes (Oxford)

Hunter, R.L. (1996) Theocritus and the Archaeology of Greek Poetry (Cambridge)

Jost, M. (1985) Sanctuaires et cultes d'Arcadie (Paris)

Lévêque, P. and Vidal-Naquet, P. (tr. A. Szegedy-Maszak) (1986) 'Epaminondas the Pythagorean, or the tactical problem of right and left', in P. Vidal-Naquet, The Black Hunter: Forms of Thought and Forms of Society in the Greek World (Baltimore), 61-82

Lewis, S. (1996) News and Society in the Greek Polis (London)

Meiggs, R. and Lewis, D. (1988) A Selection of Greek Historical Inscriptions to the End of the Fifth Century $B C$ (revised edition) (Oxford) (= ML)

Pelling, C. (2000) Literary Texts and the Greek Historian (London)

46 We need not think of this as a particularly 'foreign' notion, if we reflect upon the status of (for example) Coventry Cathedral and Dresden's Frauenkirche as symbols of the horror of the bombing of cities. More recently, we might wonder whether emphasis on the illegality of wars perceived as wrong might reflect a similar underlying need. From an outsider's point of view this could seem surprising - wars are not in an obvious way more or less wrong or destructive by virtue of the development of international law or the approval of the UN Security Council (of course, it is responses to the 2003 Iraq War which I particularly have in mind) but the concept of illegality may fulfil an emotional/rhetorical need to present wars as not merely destructive or wrong but as breaching a set of broadly accepted rules or taboos. 
- (2013) 'Intertextuality, plausibility, and interpretation', Histos 7, 1-20, http://research.ncl.ac.uk/histos/ documents/2013A01PellingIntertextualityPlausibilityandInterpretation.pdf

Prauscello, L. (2013) 'Demeter and Dionysus in the sixth century Argolid: Lasus of Hermione, the cult of Demeter Chthonia and the origins of dithyramb', in B. Kowalzig and P. Wilson (eds), Dithyramb in Context (Oxford) 76-92

Rood, T. (1998) Thucydides: Narrative and Explanation (Oxford)

Schipporeit, S. (2008) 'Enna and Eleusis', in C.A. Di Stefano (ed.), Demetra. La divinità, i santuari, il culto, la leggenda (Pisa and Rome) 41-46

Sfameni Gasparro, G. (1986) Misteri e culti misteri di Demetra (Rome)

- (2008) 'Demetra in Sicilia: tra identità e connotazioni locali', in C.A. Di Stefano (ed.), Demetra. La divinità, $i$ santuari, il culto, la leggenda (Pisa and Rome) 25-40

Sourvinou-Inwood, C. (2000) 'What is polis religion?', in R. Buxton (ed.), Oxford Readings in Greek Religion (Oxford) 13-37; previously published in O. Murray and S. Price (eds) (1990) The Greek City from Homer to Alexander (Oxford) 295-322 